\title{
New seismic zones in the Center North of Mato Grosso State - Brazil
}

Lucas Vieira Barros ${ }^{1}$, Juraci Mario de Carvalho ${ }^{1}$, Marcelo Peres Rocha ${ }^{1}$, George Sand de França ${ }^{1}$, Aline Leite Jardim Oliveira ${ }^{1}$, Brandow Lee Neri ${ }^{1}$, Darlan Portela Fontenele ${ }^{1}$ and Leticia Guedes Assunção ${ }^{1}$, Seismological Observatory - University of Brasilia - Brasilia - Brazil

Copyright 2021, SBGf - Sociedade Brasileira de Geofísica.

This paper was prepared for presentation during the $17^{\text {th }}$ International Congress of the Brazilian Geophysical Society held in Rio de Janeiro, Brazil, 8-11 November 2021 (Online Event). Contents of this paper were reviewed by the Technical Committee of the $17^{\text {th }}$ International Congress of the Brazilian Geophysical Society and do not necessarily represent any position of the SBGf, its officers or members. Electronic reproduction or storage of any part of this paper for commercial purposes without the written consent of the Brazilian Geophysical Society is prohibited.

Earthquake in the Center North of the Mato Grosso State - Brazil was first detected in January 1955, in the current Nova Maringa town, $6.2 \mathrm{mb}$ and MM (IV-V) at $380 \mathrm{~km}$ from the source. This was the largest earthquake ever detected in the entire Stable Continental Interior of the South American plate. In 1959, with the arrival of the first inhabitants to the region of Porto dos Gaúchos, earthquakes were felt with an estimated magnitude of up to 4.0 $\mathrm{mb}$. With the installation of regional stations in the Brazilian Amazon in 1980, earthquakes continued to be detected in Porto dos Gaúchos. In March 1998, an earthquake of magnitude $5.2 \mathrm{mb}$ (MM VI) was detected, and its aftershocks were studied with a local seismic network. It was determined a focal mechanism of WSW-ENE transcurrent regime, with about an extension of $5 \mathrm{~km}$. In 2005, another $5.0 \mathrm{mb}$ (MM V) earthquake occurred in the same fault and with the same focal mechanism. Studies of seismic wave attenuation, crustal structure with shallow seismic refraction, and local receiver function allowed us to determine an accurate 1D velocity model for the area. In December 2015, a new seismic area in Tapaporã was identified. The largest magnitude was $4.0 \mathrm{mb}$. New seismic areas were also identified in 2015 in Juara and Brasnorte, and in 2016 in Nova Maringa. All these seismogenic areas are in the Parecis Phanerozoic Basin, some close to each border where there are sequences of high and low gravimetric anomaly associated to a sequence of graben and horsts. The Caiabis graben is the most expressive geological characteristic presents in the border of the Parecis basin. In November of 2019, a local seismic network was deployed to study the new seismic area in Tabaporã. However, due to the coronavirus pandemic only in April of 2021 it as possible to collect data from the field. In this work, we present an upgrade of the seismicity in Porto dos Gaúchos, Tabaporã, Juara, Nova Maringa and Brasnorte. 